\title{
KEMAMPUAN MAHASISWA PROGRAM STUDI PENDIDIKAN \\ BAHASA DAN SASTRA INDONESIA FKIP UIR DALAM MENENTUKAN JENIS KALIMAT
}

\author{
Ermawati. $\mathrm{S}^{1}$, Hermaliza ${ }^{2}$, Yaiza Ike Aprilla ${ }^{3}$ \\ Universitas Islam Riau, Pekanbaru, Indonesia ${ }^{1,2,3}$ \\ ermawati.s@edu.uir.ac.idl, hermaliza@edu.uir.ac.id²,yaizaike1999@gmail.com³
}

\begin{abstract}
This research was related to the ability of students of Indonesia language and literature education in determining the type of sentence. It was conducted because obstacles were still found such as students could not distinguish simple items related to the type of sentence, especially in terms of the number of clauses and syntactic forms. The problems in this research were; (1) how was the ability of students of Indonesia language and literature education study program at FKIP UIR in determining the type of sentence based on the number of clauses?; (2) how was the ability of students of Indonesia language and literature education study program at FKIP UIR in determining the type of sentence based on the syntactic form?. Thus, this research aimed to find, analyze, describe, and conclude the ability of students of Indonesia language and literature education study program at FKIP UIR in determining sentence types based on the number of classes and their syntactical forms. The population in this research was all fourth semester that consist of 149 students and the sample was $15 \%$, namely 22 students. Data collection techniques included observation and questionnaire. The theory used refers to the opinion expressed by Alwi, et al (2003) and other expert opinions. Based on the analysis conducted it can be concluded that; (1) The ability of students of Indonesia language and literature education study program at FKIP UIR in determining the type of sentence on the number of clauses based on the students' average test score was 81.36 which was categorized "excellent"; and (2) The ability of students of Indonesia language and literature education study program at FKIP UIR in determining the type of sentence on the syntactic form based on students' average test score was 79.31 which was categorized "good".
\end{abstract}

Keywords: FKIP UIR, students' ability, type of sentence

\begin{abstract}
ABSTRAK
Penelitian ini terkait dengan kemampuan mahasiswa Program Studi Pendidikan Bahasa dan Sastra Indonesia dalam menentukan jenis kalimat. Penelitian ini perlu dilakukan karena masih ditemukan mahasiswa yang tidak bisa membedakan hal sederhana yang berkaitan dengan jenis kalimat terutama dari segi jumlah klausa dan bentuk sintaksisnya. Masalah dalam penelitian ini adalah: (1) Bagaimanakah Kemampuan Mahasiswa Program Studi Pendidikan Bahasa dan Sastra Indonesia FKIP UIR dalam Menentukan Jenis Kalimat Berdasarkan Jumlah Klausa? (2) Bagaimanakah Kemampuan Mahasiswa Program Studi Pendidikan Bahasa dan Sastra Indonesia FKIP UIR dalam Menentukan Jenis Kalimat Berdasarkan Bentuk Sintaksis? Penelitian ini bertujuan untuk menemukan, menganalisis mendeskripsikan dan menyimpulkan Kemampuan Mahasiswa Program Studi Pendidikan Bahasa dan Sastra Indonesia FKIP UIR dalam Menentukan Jenis Kalimat Berdasarkan Jumlah Klausanya dan Bentuk Sintaksisnya. Populasi dalam penelitian ini adalah seluruh mahasiswa semester 4 yang berjumlah 149 orang dan sampelnya adalah sebanyak $15 \%$ yakni 22 orang mahasiswa. Teknik pengumpulan data dalam penelitian ini antara lain observasi, dan pemberian tes (angket). Teori yang digunakan mengacu pada pendapat yang dikemukakan oleh Alwi, dkk. (2003) dan pendapat ahli lainnya. Berdasarkan analisis yang dilakukan, dapat disimpulkan bahwa (1) Kemampuan Mahasiswa Program Studi Pendidikan Bahasa dan Sastra Indonesia FKIP UIR dalam Menentukan Jenis Kalimat Berdasarkan Jumlah Klausanya secara
\end{abstract}

Kemampuan Mahasiswa Program Studi Pendidikan Bahasa dan Sastra Indonesia FKIP UIR dalam Menentukan Jenis Kalimat 
keseluruhan dilihat dari perolehan rata-rata nilai tes mahasiswa adalah 81,35 yang dikategorikan baik sekali (2) Kemampuan Mahasiswa Program Studi Pendidikan Bahasa dan Sastra Indonesia FKIP UIR dalam Menentukan Jenis Kalimat Berdasarkan Bentuk Sintaksisnya secara keseluruhan dilihat dari perolehan rata-rata nilai tes mahasiswa adalah 79,31 yang dikategorikan baik.

\section{Kata Kunci: FKIP UIR, jenis kalimat, kemampuan mahasiswa}

\section{PENDAHULUAN}

Bahasa merupakan sarana yang sangat diperlukan manusia agar dapat berkomunikasi dan berhubungan dengan sesamanya. Melalui bahasa, seseorang dapat mengungkapkan dan menyampaikan apa pun yang diinginkannya kepada orang lain. Begitu pentingnya bahasa dalam kehidupan sehari-hari tidak dapat dielakkan lagi karena hampir setiap aktivitas dan kegiatan yang dilakukan melibatkan bahasa, baik bahasa lisan maupun bahasa tulis. Sebagaimana ditegaskan ahli bahwa bahasa adalah sistem lambang bunyi yang arbitrer yang digunakan untuk bekerja sama, berinteraksi dan mengidentifikasikan diri (Chaer, 2007:32; Alber dan Febria, 2018:78; Nalenan, 2019:103-104). Bahasa yang menjadi sarana komunikasi yang sangat penting dan utama di negara ini adalah bahasa Indonesia.

Bahasa Indonesia ialah bahasa negara yang dipergunakan oleh rakyat ataupun orang Indonesia. Bahasa Indonesia menjadi bahasa pertama (B1) bagi masyarakat yang tinggal di kota besar dan menjadi bahasa kedua (B2) bagi masyarakat yang tinggal di pedesaan (karena bahasa pertama yang digunakan adalah bahasa ibu/bahasa daerah masing-masing). Walaupun demikian, bahasa Indonesia tetap dijadikan sebagai salah satu mata pelajaran yang wajib dan harus diajarkan di sekolah (SD, SMP (yang sederajat) dan SMA (yang sederajat) hingga perguruan tinggi (PT). Begitu pentingnya bahasa Indonesia tentu tidak diragukan lagi oleh pemakainya, termasuk bagi penulis sendiri sebagai warganegara Indonesia. Dari sekian banyak aspek yang dibahas dan disuguhkan dalam mata pelajaran bahasa Indonesia, pembahasan atau materi tentang kalimat (bagian dari sintaksis) menjadi bagian yang cukup menyulitkan bagi kalangan pelajar dan mahasiswa di perguruan tinggi (PT) khususnya di Program Studi Pendidikan Bahasa dan
Sastra Indonesia FKIP UIR, berdasarkan pengalaman penulis mengajarkan mata kuliah terkait. Namun, sebelum membahas mengenai mahasiswa, penulis perlu menjelaskan tentang sintaksis terlebih dahulu.

Salah satu cabang dari ilmu bahasa adalah sintaksis. Sintaksis merupakan bagian atau cabang dari tata bahasa yang fokus membicarakan tentang frasa, klausa dan kalimat. Mengutip beberapa pendapat pakar bahasa, sintaksis adalah cabang tata bahasa yang membicarakan seluk beluk frase, klausa, kalimat dan wacana (Ramlan, 2005:18). Selanjutnya, sintaksis adalah subsistem kebahasaan yang membicarakan penataan danpengaturan kata-kata itu ke dalam satuansatuan yang lebih besar, yang disebut satuan sintaksis, yakni kata, frasa, klausa, kalimat dan wacana (Chaer, 2009:3). Selain itu, Stryker, dalam (Tarigan, 2009) menjelaskan "The study of the patterns by which word are combined to make sentences is syntax".

Menurut Alwi dkk (2003:311) "Kalimat adalah satuan bahasa terkecil, dalam wujud lisan atau tulisan, yang mengungkapkan pikiran yang utuh". Selain itu, menurut Chaer (2009:44) "Kalimat adalah satuan sintaksis yang disusun dari konstituen dasar, yang biasanya berupa klausa, dilengkapi dengan konjungsi bila diperlukan, serta disertai dengan intonasi final". Pengertian tersebut tidak jauh berbeda dengan pendapat Finoza (2009:149) "Kalimat adalah bagian ujaran atau tulisan yang mempunyai struktur minimal subjek (S) dan predikat (P) dan intonasi finalnya menunjukkan bagian ujaran atau tulisan itu sudah lengkap dengan makna (bernada berita, tanya, atau perintah)". Pendapat Finoza tersebut juga dipertegas oleh Putrayasa (2008:21) "Minimal, kalimat terdiri atas unsur subjek dan predikat".

Jenis kalimat berdasarkan jumlah klausanya dibedakan menjadi dua yaitu

Kemampuan Mahasiswa Program Studi Pendidikan Bahasa dan Sastra Indonesia FKIP UIR dalam Menentukan Jenis Kalimat 
kalimat tunggal dan kalimat majemuk.

Sebagaimana diungkapkan oleh Alwi dkk (2003:336) "Berdasarkan jumlah klausanya, kalimat dapat dibagi atas kalimat tunggal dan kalimat majemuk". Kalimat tunggal adalah kalimat yang memiliki satu subjek dan satu predikat atau kalimat yang mempunyai satu klausa. Menurut Alwi dkk (2003:338) "Kalimat tunggal adalah kalimat yang terdiri atas satu klausa". Hal tersebut dipertegas oleh Chaer (2007:243) "Kalau klausanya hanya satu, maka kalimat tersebut disebut kalimat tunggal". Menurut Alwi dkk (2003:40) "Kalimat majemuk adalah kalimat yang terdiri atas lebih dari satu proposisi sehingga mempunyai paling tidak dua predikat yang tidak dapat dijadikan satu kesatuan. Karena sifat itu, maka kalimat majemuk selalu berwujud dua klausa atau lebih". Pendapat tersebut sejalan dengan pendapat Chaer (2007:243) "Kalau klausa di dalam sebuah kalimat terdapat lebih dari satu, maka kalimat itu disebut kalimat majemuk"

Berdasarkan bentuk sintaksisnya kalimat dibagi atas kalimat deklaratif, kalimat interogatif, kalimat imperatif dan kalimat eksklamatif. Sebagaimana diungkapkan oleh Alwi dkk (2003:337) "Berdasarkan bentuk atau kategori sintaksisnya, kalimat lazim dibagi atas (1) kalimat deklaratif atau kalimat berita, (2) kalimat imperatif atau kalimat perintah, (3) kalimat interogatif atau kalimat tanya, dan (4) kalimat eksklamatif atau kalimat seruan". Kalimat berita adalah kalimat yang isinya memberitahukan sesuatu. Hal tersebut sesuai pendapat Alwi dkk (2003:353) "Dalam pemakaiannya bahasa bentuk kalimat deklaratif umumnya digunakan oleh pembicara/penulis untuk membuat pernyataan sehingga isinya merupakan berita bagi pendengar atau pembaca". Kalimat perintah adalah kalimat yang bertujuan memberikan perintah kepada orang lain untuk melakukan sesuatu. Biasanya diakhiri tanda seru (!) atau tanda titik (.). Menurut Finoza (2009:169) "Pada bahasa lisan kalimat ini berintonasi akhir menurun dan pada bahasa tulis kalimat ini diakhiri dengan tanda seru atau tanda titik". Kalimat interogatif atau kalimat tanya merupakan kalimat yang berfungsi untuk meminta jawaban atau informasi dari seseorang. Menurut Alwi dkk (2003:358) "Bentuk kalimat interogatif biasanya digunakan untuk meminta (1) jawaban 'ya' atau 'tidak', atau (2) informasi mengenai sesuatu atau seseorang dari lawan bicara atau pembaca". Kalimat tanya biasanya diakhiri dengan tanda tanya (?).Kalimat eksklamatif adalah kalimat yang digunakan untuk mengungkapkan keheranan atau kekaguman terhadap sesuatu. Sebagaimana diungkapkan oleh Alwi dkk (2003:362) "Kalimat eksklamatif ini, yang juga dinamakan kalimat interjeksi biasa digunakan untuk menyatakan perasaan kagum atau heran".

Permasalahan dan persoalan terkait kemampuan mahasiswa Program Studi Pendidikan Bahasa dan Sastra Indonesia yang menjadi titik berat penelitian ini, masih ditemukan mahasiswa yang tidak bisa membedakan atau belum bisa menentukan hal sederhana yang berkaitan dengan bidang sintaksis. Hal sederhana yang dimaksud misalnya dari segi jumlah klausa dan bentuk sintaksisnya, padahal itulah dasar-dasar yang harus diketahui dan dipahami oleh mahasiswa Program Studi Pendidikan Bahasa dan Sastra Indonesia (khususnya FKIP UIR) sebagai calon guru bahasa Indonesia kelak. Terkait dengan fenomena yang penulis temukan itulah penelitian ini perlu dilakukan Berdasarkan persoalan tersebut, masalah yang diangkat dalam penelitian ini adalah (1) Bagaimanakah Kemampuan Mahasiswa Program Studi Pendidikan Bahasa dan Sastra Indonesia FKIP UIR dalam Menentukan Jenis Kalimat Berdasarkan Jumlah Klausa?

Bagaimanakah Kemampuan Mahasiswa Program Studi Pendidikan Bahasa dan Sastra Indonesia FKIP UIR dalam Menentukan Jenis Kalimat Berdasarkan Bentuk Sintaksis?

\section{METODOLOGI PENELITIAN}

Penelitian ini dilakukan di kampus Universitas Islam Riau, khususnya di kampus gedung C Fakultas Keguruan dan Ilmu Pendidikan. Penelitian ini dilaksanakan selama enam bulan terhitung mulai bulan Maret sampai dengan bulan Agustus 2019. Populasi yang digunakan dalam penelitian ini merujuk

Kemampuan Mahasiswa Program Studi Pendidikan Bahasa dan Sastra Indonesia FKIP UIR dalam Menentukan Jenis Kalimat 
pendapat Arikunto. Menurut Arikunto

(2009:173) "Populasi adalah keseluruhan subjek penelitian". Pendapat tersebut dipertegas oleh Sugiono dalam Hikmat (2011:60) "Populasi adalah wilayah generalisasi yang terdiri atas: objek/subjek yang mempunyai kualitas dan karakteristik tertentu yang ditetapkan oleh peneliti untuk dipelajari dan kemudian ditarik kesimpulan". Populasi dalam penelitian ini adalah seluruh mahasiswa semester IV (kelas A s.d. D) Program Studi Pendidikan Bahasa dan Sastra Indonesia FKIP UIR.

Untuk penentuan sampel penelitian, penulis juga merujuk pendapat Arikunto. Menurut Arikunto (2009:174) "Sampel adalah sebagian atau wakil populasi yang diteliti". Dengan kata lain, sampel merupakan anggota populasi yang akan dijadikan sampel dalam suatu penelitian. Selain itu, Hikmat (2011:63) mengemukakan "Sampel Random Sampling yakni cara pengambilan sampel dari semua anggota populasi yang dilakukan secara acak tanpa memperhatikan strata yang ada di dalam anggota populasi itu. Cara ini dilakukan bila anggota populasi dianggap homogen (memiliki kesamaan)". Bertolak dari kutipan tersebut maka penulis menggunakan teknik sampel random sampling, yakni upaya pengambilan sampel dengan cara acak dengan jumlah sampel sebanyak $15 \%$ dari populasi yang ada yaitu 149 orang sehingga diperoleh 22,35 kemudian dibulatkan menjadi 22 orang yang dijadikan sampel. Hal tersebut sesuai dengan apa yang dikemukakan oleh Arikunto (2009:134) “Tetapi, jika jumlah subjeknya besar, dapat diambil antara $10-15 \%$ atau 20 $25 \%$ atau lebih...".

Penelitian ini menggunakan metode deskriptif. Penelitian yang bersifat deskriptif, bertujuan menggambarkan secara tepat sifatsifat suatu individu, keadaan, gejala, atau kelompok tertentu, atau untuk menentukan frekuensi atau penyebaran suatu gejala frekuensi adanya hubungan tertentu atau suatu gejala dan gejala lain di masyarakat (Ismawati, 2011:38; Alber dan Hermaliza, 2020:2). Selain itu, penelitian ini termasuk dalam jenis penelitian lapangan dan pendekatan kuantitatif. Data dikumpulkan melalui observasi dan pemberian tes (angket) yang dilaksanakan pada Senin, 20 Mei 2019 (kelas A dan B); Rabu, 22 Mei 2019 (kelas D) dan Kamis, 23 Mei 2019 (kelas C).

\section{HASIL DAN PEMBAHASAN}

Pada bagian ini penulis menganalisis kemampuan mahasiswa Program Studi Pendidikan Bahasa dan Sastra Indonesia FKIP UIR dalam menentukan Jenis Kalimat. Analisis difokuskan pada kemampuan mahasiswa dalam menentukan jenis kalimat berdasarkan jumlah klausanya dan jenis kalimat berdasarkan bentuk sintaksisnya. Analisis data ini dilakukan atas jawaban mahasiswa Program Studi Pendidikan Bahasa dan Sastra Indonesia FKIP UIR sebagai sampel penelitian yang berjumlah 22 orang, dan terbagi atas 2 soal dalam bentuk wacana. Dalam wacana tersebut terdapat 30 jumlah kalimat yang terbagi atas 5 kalimat tunggal, 5 kalimat majemuk, 5 kalimat berita, 5 kalimat tanya, 5 kalimat perintah dan 5 kalimat seru.

1. Kemampuan Mahasiswa Program Studi Pendidikan Bahasa dan Sastra Indonesia FKIP UIR dalam Menentukan Jenis Kalimat Berdasarkan Jumlah Klausanya.

Kemampuan mahasiswa dalam menentukan jenis kalimat berdasarkan jumlah klausanya terbagi atas dua yakni kemampuan mahasiswa menentukan kalimat tunggal dan kemampuan mahasiswa menentukan kalimat majemuk. Wacana yang diberikan terdiri atas 10 kalimat yang di dalamnya mencakup kalimat tunggal dan kalimat majemuk.

a. Kemampuan Mahasiswa dalam Menentukan Kalimat Tunggal

Berdasarkan analisis yang dilakukan, diketahui bahwa jumlah nilai mahasiswa dalam menentukan kalimat tunggal adalah 1780 dari 22 orang mahasiswa. Penulis membagi nilai 1780 dengan jumlah sampel yakni 22 orang mahasiswa dan rata-rata yang diperoleh adalah 80.90. Dari 22 orang sampel, mahasiswa yang memperoleh nilai 100 dengan kategori baik sekali berjumlah 7 orang. Mahasiswa yang memperoleh nilai 80 dengan kategori sama yakni baik sekali berjumlah 10

Kemampuan Mahasiswa Program Studi Pendidikan Bahasa dan Sastra Indonesia FKIP UIR dalam Menentukan Jenis Kalimat 
orang. Mahasiswa yang memperoleh nilai 60 dengan kategori cukup berjumlah 4 orang dan mahasiswa yang memperoleh nilai 40 dengan kategori gagal berjumlah 1 orang. Dengan demikian, jumlah mahasiswa yang berkategori baik sekali dalam menentukan jenis kalimat tunggal berjumlah 17 dari 22 orang mahasiswa.

\section{b. Kemampuan Mahasiswa dalam Menentukan Kalimat Majemuk \\ Berdasarkan analisis yang dilakukan,} diketahui bahwa jumlah nilai mahasiswa dalam menentukan kalimat majemuk adalah 1800 dari 22 orang mahasiswa. Penulis membagi nilai 1800 dengan jumlah sampel yakni 22 orang mahasiswa dan rata-rata yang diperoleh adalah 81.81. Dari 22 orang sampel, mahasiswa yang memperoleh nilai 100 dengan kategori baik sekali berjumlah 8 orang. Mahasiswa yang memperoleh nilai 80 dengan kategori sama yakni baik sekali berjumlah 10 orang. Mahasiswa yang memperoleh nilai 60 dengan kategori cukup berjumlah 2 orang dan mahasiswa yang memperoleh nilai 40 dengan kategori gagal berjumlah 2 orang. Dengan demikian, jumlah mahasiswa yang berkategori baik sekali dalam menentukan jenis kalimat majemuk berjumlah 18 dari 22 orang mahasiswa.

Jumlah nilai mahasiswa dalam menentukan jenis kalimat berdasarkan jumlah klausanya adalah 1790 dari 22 orang mahasiswa. Penulis membagi nilai 1790 dengan jumlah sampel yakni 22 orang mahasiswa dan rata-rata yang diperoleh adalah 81.36. Dari 22 orang sampel, mahasiswa yang memperoleh nilai 100 dengan kategori baik sekali berjumlah 4 orang. Mahasiswa yang memperoleh nilai 90 dengan kategori sama yakni baik sekali berjumlah 2 orang. Mahasiswa yang memperoleh nilai 80 dengan kategori baik sekali berjumlah 11 orang. Mahasiswa yang memperoleh nilai 70 dengan kategori baik berjumlah 3 orang. Mahasiswa yang memperoleh nilai 60 dengan kategori cukup berjumlah 2 orang. Dengan demikian, kemampuan mahasiswa Program Studi Pendidikan Bahasan dan Sastra Indonesia FKIP UIR dalam menentukan jenis kalimat berdasarkan jumlah klausanya berkategori baik sekali. Artinya, mahasiswa dapat dikatakan mampu dalam menentukan jenis kalimat berdasarkan jumalah klausanya dengan nilai rata-rata 81.36.

Kemampuan mahasiswa Program Studi Pendidikan Bahasa dan Sastra Indonesia FKIP UIR dalam menentukan jenis kalimat berdasarkan jumlah klausanya dapat dilihat pada diagram 1 .

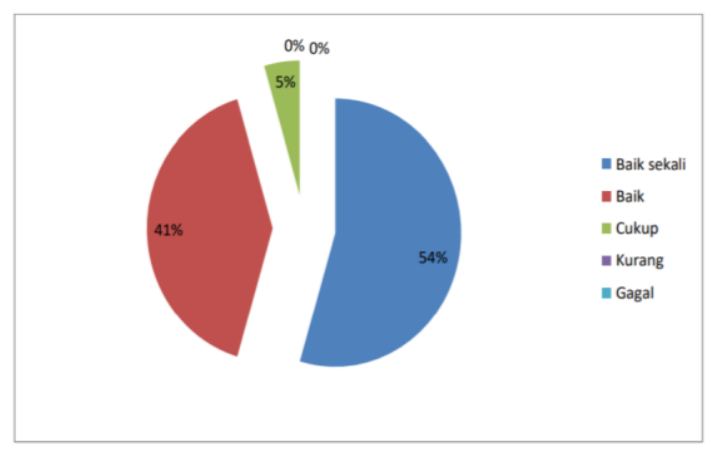

Diagram 1. Kemampuan mahasiswa Program Studi Pendidikan Bahasa dan Sastra Indonesia FKIP UIR dalam menentukan jenis kalimat berdasarkan jumlah klausanya

Diagram 1 menunjukkan bahwa kemampuan mahasiswa Program Studi Pendidikan Bahasa dan Sastra Indonesia FKIP UIR dalam menentukan jenis kalimat berdasarkan jumlah klausanya secara keseluruhan atau totalnya adalah 22 orang sampel (100\%). 12 sampel (54\%) berkemampuan baik sekali, 9 sampel $(41 \%)$ Baik, 1 sampel (5\%) berkemampuan cukup sedangkan yang berkemampuan kurang dan gagal tidak ditemukan atau nol (0\%).

2. Kemampuan Mahasiswa Program Studi Pendidikan Bahasa dan Sastra Indonesia FKIP UIR dalam Menentukan Jenis Kalimat Berdasarkan Bentuk Sintaksisnya Kemampuan mahasiswa dalam menentukan jenis kalimat berdasarkan bentuk sintaksisnya terbagi atas empat yakni kemampuan mahasiswa menentukan kalimat berita, puan mahasiswa menentukan kalimat tanya, puan mahasiswa menentukan kalimat perintah dan kemampuan mahasiswa menentukan kalimat seru. Wacana yang 
diberikan terdiri atas 20 kalimat yang didalamnya mencakup kalimat berita, kalimat tanya, kalimat perintah dan kalimat seru.

\section{a. Kemampuan Mahasiswa dalam Menentukan Kalimat Berita}

Berdasarkan analisis yang dilakukan, diketahui bahwa jumlah nilai mahasiswa dalam menentukan kalimat berita adalah 1740 dari 22 orang mahasiswa. Penulis membagi nilai 1740 dengan jumlah sampel yakni 22 orang mahasiswa dan rata-rata yang diperoleh adalah 79.09. Dari 22 orang sampel, mahasiswa yang memperoleh nilai 100 dengan kategori baik sekali berjumlah 5 orang. Mahasiswa yang memperoleh nilai 80 dengan kategori sama yakni baik sekali berjumlah 13 orang. Mahasiswa yang memperoleh nilai 60 dengan kategori cukup berjumlah 3 orang dan mahasiswa yang memperoleh nilai 20 dengan kategori gagal berjumlah 1 orang.

\section{b. Kemampuan Mahasiswa dalam Menentukan Kalimat Tanya}

Analisis menunjukkan bahwa jumlah nilai mahasiswa dalam menentukan kalimat tanya adalah 2200 dari 22 orang mahasiswa. Penulis membagi nilai 2200 dengan jumlah sampel yakni 22 orang mahasiswa dan ratarata yang diperoleh adalah 100. Dari 22 orang sampel, mahasiswa yang memperoleh nilai 100 dengan kategori baik sekali berjumlah 22 orang mahasiswa. Dengan demikian, mahasiswa dikatakan berkemampuan atau berkategori baik sekali dalam menentukan kalimat tanya karena seluruh mahasiswa berhasil menjawab dengan benar semua kalimat.

\section{c. Kemampuan Mahasiswa dalam Menentukan Kalimat Perintah}

Selanjutnya, analisis yang dilakukan juga menunjukkan bahwa jumlah nilai mahasiswa dalam menentukan kalimat perintah adalah 1480 dari 22 orang mahasiswa. Penulis membagi nilai 1480 dengan jumlah sampel yakni 22 orang mahasiswa dan ratarata yang diperoleh adalah 67.27. Dari 22 orang sampel, mahasiswa yang memperoleh nilai 100 dengan kategori baik sekali berjumlah 2 orang mahasiswa. Mahasiwa yang memperoleh nilai 80 dengan kategori baik sekali berjumlah 7 orang. Dengan demikian, mahasiswa dikatakan berkemampuan atau berkategori baik sekali dalam menentukan kalimat perintah karena seluruh mahasiswa berhasil menjawab dengan benar semua kalimat.

d. Kemampuan Mahasiswa dalam Menentukan Kalimat Seru

Terakhir, berdasarkan analisis data yang dilakukan dapat dilihat bahwa jumlah nilai mahasiswa dalam menentukan kalimat seru adalah 1560 dari 22 orang mahasiswa. Penulis membagi nilai 1560 dengan jumlah sampel yakni 22 orang mahasiswa dan rata-rata yang diperoleh adalah 70.90. Dari 22 orang sampel, mahasiswa yang memperoleh nilai 100 dengan kategori baik sekali berjumlah 1 orang. Mahasiswa yang memperoleh nilai 80 dengan kategori sama yakni baik sekali berjumlah 12 orang. Mahasiswa yang memperoleh nilai 60 dengan kategori cukup berjumlah 7 orang dan mahasiswa yang memperoleh nilai 20 dengan kategori gagal berjumlah 2 orang.

Jumlah nilai mahasiswa dalam menentukan jenis kalimat berdasarkan bentuk sintaksisnya adalah 1745 dari 22 orang mahasiswa. Penulis membagi nilai 1745 dengan jumlah sampel yakni 22 orang mahasiswa dan rata-rata yang diperoleh adalah 79.31. Dari 22 orang sampel, mahasiswa yang memperoleh nilai 90 dengan kategori baik sekali berjumlah 5 orang. Mahasiswa yang memperoleh nilai 85 dengan kategori sama yakni baik sekali berjumlah 3 orang. Mahasiswa yang memperoleh nilai 80 dengan kategori baik sekali berjumlah 4 orang. Mahasiswa yang memperoleh nilai 75 dengan kategori baik berjumlah 5 orang. Mahasiswa yang memperoleh nilai 70 dengan kategori cukup berjumlah 4 orang. Mahasiswa yang memperoleh nilai 65 dengan kategori cukup berjumlah 1 orang. Dengan demikian, kemampuan mahasiswa Program Studi Pendidikan Bahasan dan Sastra Indonesia FKIP UIR dalam menentukan jenis kalimat berdasarkan bentuk sintaksisnya yang berkategori baik dengan nilai rata-rata 79.31.

Kemampuan Mahasiswa Program Studi Pendidikan Bahasa dan Sastra Indonesia FKIP UIR dalam Menentukan Jenis Kalimat 
Kemampuan mahasiswa Program

Studi Pendidikan Bahasa dan Sastra Indonesia FKIP UIR dalam menentukan jenis kalimat berdasarkan bentuk sintaksisnya dapat dilihat pada diagram 2 .

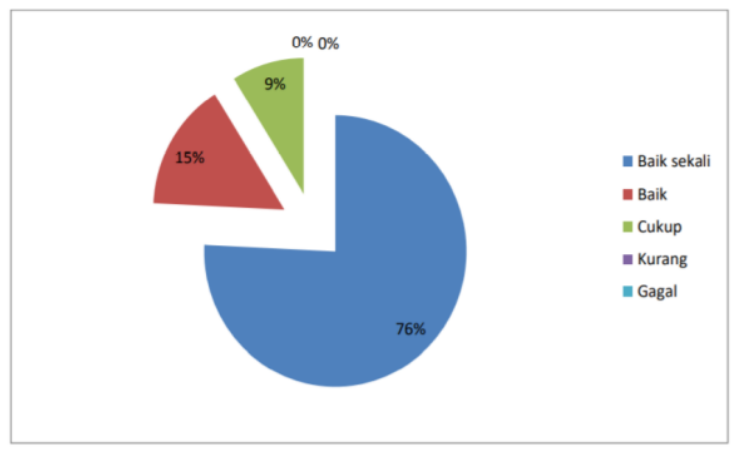

Diagram 2. Kemampuan mahasiswa Program Studi Pendidikan Bahasa dan Sastra Indonesia FKIP UIR dalam menentukan jenis kalimat berdasarkan bentuk sintaksisnya.

Diagram 2. Menunjukkan bahwa kemampuan mahasiswa Program Studi Pendidikan Bahasa dan Sastra Indonesia FKIP UIR dalam menentukan jenis kalimat berdasarkan bentuk sintaksisnya secara keseluruhan atau total dari 22 orang sampel (100\%). 17 sampel (76\%) berkemampuan baik sekali, 3 sampel (15\%) berkemampuan baik, 2 sampel (9\%) berkemampuan cukup sedangkan yang berkemampuan kurang dan gagal tidak ditemukan atau nol (0\%).

Rekapitulasi kemampuan mahasiswa Program Studi Pendidikan Bahasa dan Sastra Indonesia FKIP UIR dalam menentukan jenis kalimat. Rekapitulasi dari kedua aspek yang diteliti yaitu jenis kalimat berdasarkan jumlah klausanya dan jenis kalimat berdasarkan bentuk sintaksisnya. Kemampuan mahasiswa Program Studi Pendidikan Bahasa dan Sastra Indonesia FKIP UIR dalam menentukan jenis kalimat berdasarkan jumlah klausanya dengan nilai rata-rata 81.35 dengan kategori baik sekali. Kemampuan mahasiswa Program Studi Pendidikan Bahasa dan Sastra Indonesia FKIP UIR dalam menentukan jenis kalimat berdasarkan bentuk sintaksisnya dengan nilai rata-rata 79.31 dengan kategori baik.

\section{SIMPULAN}

Berdasarkan penelitian dan analisis data yang dilakukan dapat disimpulkan bahwa:

1. Kemampuan mahasiswa Program Studi Pendidikan Bahasa dan Sastra Indonesia FKIP UIR dalam menentukan jenis kalimat berdasarkan jumlah klausanya secara keseluruhan dilihat dari perolehan rata-rata nilai tes mahasiswa adalah 81,35 dikategorikan baik sekali. Tingkat kemampuan mahasiswa Program Studi Pendidikan Bahasa dan Sastra Indonesia FKIP UIR dalam menentukan jenis kalimat berdasarkan jumlah klausanya terdiri atas 22 orang sampel (100\%), sebanyak 12 sampel (54\%) berkemampuan baik sekali, sebanyak 9 sampel (41\%) berkemampuan baik, sebanyak 1 sampel (5\%) berkemampuan cukup dan tidak ditemukan yang berkemampuan kurang dan gagal $(0 \%)$.

2. Kemampuan mahasiswa Program Studi Pendidikan Bahasa dan Sastra Indonesia FKIP UIR dalam menentukan jenis kalimat berdasarkan bentuk sintaksisnya secara keseluruhan dilihat dari perolehan rata-rata nilai tes mahasiswa adalah 79,31 dikategorikan baik. Tingkat kemampuan mahasiswa Program Studi Pendidikan Bahasa dan Sastra Indonesia FKIP UIR dalam menentukan jenis kalimat berdasarkan bentuk sintaksisnya terdiri atas 22 sampel (100\%), sebanyak 17 sampel (76\%) berkemampuan baik sekali, sebanyak 3 sampel (15\%) berkemampuan baik, sebanyak 2 sampel (9\%) berkemampuan cukup, dan tidak ditemukan yang berkemampuan kurang dan berkemampuan gagal $(0 \%)$.

\section{REFERENSI}

Alber, A. \& Febria, R. (2018). Analisis Kesalahan Berbahasa Tataran Sintaksis dalam Kumpulan Makalah Mahasiswa Universitas Islam Riau. GERAM, 6(2). https://doi.org/https://doi.org/10.25299/g eram.2018.vol6(2).2143

Alber, A. dan Hermaliza. (2020). Kemampuan Menganalisis Kesalahan Berbahasa Mahasiswa Program Studi Pendidikan Bahasa dan Sastra Indonesia Universitas

Kemampuan Mahasiswa Program Studi Pendidikan Bahasa dan Sastra Indonesia FKIP UIR dalam Menentukan Jenis Kalimat 
Islam Riau. Jurnal Sastra Indonesia, 9(1), 1-10. https://doi.org/https://doi.org/10.15294/js i.v9i1.36366

Alwi, H. dkk. (2003). Tata Bahasa Baku Bahasa Indonesia. Jakarta: Balai Pustaka.

Arikunto, S. (2009). Prosedur Penelitian Suatu Pendekatan Praktik. Jakarta: Rineka Cipta.

Chaer, A. (2007). Linguistik Umum. Jakarta: Rineka Cipta.

Chaer, A. (2009). Sintaksis Bahasa Indonesia (Pendekatan Proses). Jakarta: Rineka Cipta.

Finoza, L. (2009). Komposisi Bahasa Indonesia. Jakarta: Diksi Insan Mulia.

Hikmat, M. M. (2011). Metode Penelitian Dalam Perspektif Ilmu Komunikasi dan Sastra. Yogyakarta: Graha Ilmu.

Ismawati, E. (2011). Metode Penelitian Pendidikan Bahasa dan Sastra. Surakarta: Yuma Pressindo.

Nalenan, J. S. (2019). Bentuk Bahasa Kasual Guyub Tutur di Wilayah Perumahan BTN Kefamenanu. JUBINDO, 4(1). Retrieved from http://jurnal.unimor.ac.id/JBI/article/view /202/196

Putrayasa, I. B. (2008). Analisis Kalimat (Fungsi, Kategori, dan Peran). Bandung: Refika Aditama.

Ramlan, M. (2005). Ilmu Bahasa Indonesia Sintaksis. Yogyakarta: C.V. Karyono.

Tarigan, H. G. (2009). Pengajaran Sintaksis. Bandung: Angkasa.

Kemampuan Mahasiswa Program Studi Pendidikan Bahasa dan Sastra Indonesia FKIP UIR dalam Menentukan Jenis Kalimat 